\title{
Quality Evaluation of Composite Bread Produced from Wheat, Maize and Orange Fleshed Sweet Potato Flours
}

\author{
Igbabul Bibiana ${ }^{1,2, *}$, Num Grace ${ }^{2}$, Amove Julius ${ }^{2}$ \\ ${ }^{1}$ Department of Food Science and Technology, University of Uyo, Uyo Nigeria \\ ${ }^{2}$ Department of Food Science and Technology, University of Agriculture, Makurdi Nigeria \\ *Corresponding author: bibideke@yahoo.com
}

Received June 03, 2014; Revised July 07, 2014; Accepted July 10, 2014

\begin{abstract}
The research was carried out to evaluate the effect of addition of yellow maize (YM) and orange fleshed sweet potato (OFSP) flours on the quality of wheat bread. Maize and sweet potato were processed into flour and mixed with wheat flour for bread production. Five samples of bread were produced and denoted as Samples A to E. Sample A was the control with $100 \%$ wheat flour, while Sample B to E had maize and sweet potato flours added in an increasing order of 5 to $20 \%$. The physical properties of the bread loaves were evaluated and the result decreased significantly with increasing levels of yellow maize and orange fleshed sweet potato flours. The loaf volume varied from 340 to $182 \mathrm{~cm}^{3}$ and the bread specific volume ranged from 1.35 to $0.99 \mathrm{~cm}^{3} / \mathrm{g}$. The result of the proximate composition showed that moisture and protein contents decreased significantly $(\mathrm{p}<0.05)$ with increase in yellow maize and orange fleshed potato flours varying from 34.97 to $29.97 \%$ and 13.12 to $7.67 \%$ respectively. The fat, crude fibre, ash and carbohydrate contents of the bread samples generally increased significantly $(p<0.05)$ with increase in maize and orange fleshed potato flours. The result of the mineral content revealed that $\beta$-carotene and calcium increased significantly with increased levels of maize and sweet potato. The values of magnesium iron and phosphorus in the bread samples had no definite trend. The result of the sensory properties showed that there was significant difference in the texture and taste of $100 \%$ wheat bread and the other samples. The $100 \%$ wheat bread recorded the highest scores in all the parameters evaluated however all the other samples were well accepted. There was a decrease in the values of overall acceptability, appearance and flavor of the bread samples with increasing levels of maize and sweet potato flours but the decrease was not significantly different.
\end{abstract}

Keywords: composite bread, orange fleshed sweet potatoes, yellow maize flour

Cite This Article: Igbabul Bibiana, Num Grace, and Amove Julius, "Quality Evaluation of Composite Bread Produced from Wheat, Maize and Orange Fleshed Sweet Potato Flours." American Journal of Food Science and Technology, vol. 2, no. 4 (2014): 109-115. doi: 10.12691/ajfst-2-4-1.

\section{Introduction}

Bread can be described as a fermented confectionary product produced mainly from wheat flour, water, yeast and salt by a series of processes involving mixing, kneading, proofing, shaping and baking [1]. Bread is an important staple food in both developing and developed countries and constitutes one of the most important sources of nutrients such as carbohydrate, protein, fibre, vitamins and minerals in the diets of many people worldwide [2]. The consumption of bread in Nigeria is on a steady increase because it is a convenient and ready to eat food [3] normally consumed at breakfast, lunch, and sometimes dinner.

Wheat, the basic ingredient in bread production is imported into Nigeria [4] involving huge expenditure of foreign exchange leading to high cost of the bread. In order to make bread affordable by low income earners who constitute the larger population of consumers, there is the need to use novel sources of crops such as orange fleshed sweet potato(OFSW) and yellow maize (YM) as flour substitute for the wheat. Thus maize and sweet potato can be used to produce composite flours for bread production. Yellow maize and orange fleshed potato is reported to be rich in $\beta$ carotene (precursor of vitamin $\mathrm{A}$ ) and other nutrients $[5,6]$, therefore OFSW and YM would solve the problem of vitamin A deficiency reported by WHO [7].

Maize (Zea mays) is one of the most important cereal grains in the world, it serves as a staple food for approximately 400 million people in developing countries and it is used as a food ingredient and animal feed [8]. About half of the estimated 603 million tones world production of maize is produced in the developing countries including Nigeria [9]. Various types of maize exist including pop, flint, dent, floury and sweet cultivars which have different physicochemical properties. The yellow maize cultivar was chosen for this work because it is rich in beta-carotene, a pro vitamin A that enhances good eye sight in children and adults. According to [10] a large number of deaths in developing countries such as Nigeria are linked to chronic malnutrition; some of the problems caused by deficient diets include scurvy, night blindness, kwashiorkor and anemia. 
Sweet potato (Ipomoea batatas) is another of the world's most important food crops and an important staple in Nigeria and other developing countries $[5,8]$. It is a low input crop and is used as vegetable, a desert, a source of starch and animal feed [11]. In Nigeria, sweet potato is mostly consumed as a snack (asondo), roasted, boiled, used with fresh yams in pounded yam and as a sweetener in beverage production. Processing sweet potato into flour would increase its utilization and can serve as a source of nutrients such as carbohydrates, beta-carotene (pro vitamin $\mathrm{A}$ ), vitamin $\mathrm{C}$, vitamin $\mathrm{B}_{6}$, minerals such as calcium, phosphorus, iron, potassium, magnesium and zinc and can contribute to the color, flavor and dietary fibre of processed food products such as bread [5,12,13,14] and also enhance its use in other food preparations, [15]. The development of appealing processed products from composite flour of sweet potatoes will therefore play a major role in raising awareness on the potential of the crop. The beta carotene content would be very useful in alleviating vitamin A deficiency among children below six years and adults. The prevalence of vitamin A deficiency in Nigeria and other African countries is very high. The use of sweet potatoes as substitute for sugar would reduce the quantity of sugar needed for bread production leading to lower cost of production and price of bread and enhanced health for the consumers.

The production of composite flours using various crops for confectionary and bakery goods has been carried out by many researchers, among which are; cassava/wheat flour [16] wheat/ taro flour [17], wheat/ pumpkin flour [18] and tiger-nut/wheat flour [19]. However very little information is available on the composite flour of maize/sweet potatoes/wheat for bread production. According to [20] Composite flour technology has many advantages among which are; it plays a vital role to complement the deficiency of essential nutrients. It saves hard currency; promote high yielding local plant species and enhances overall use of domestic agriculture. Thus the aim of this work is bread production from the composite flours of yellow maize, orange fleshed potatoes and wheat, which would ensure food security, enhanced health, combat malnutrition problems, increase farming and economic activities on African continent leading to wealth creation.

\section{Materials and Methods}

\subsection{Source of Raw Materials}

Wheat flour (Golden penny), yellow maize, salt, sugar (sucrose), bread improver, and dry baker's yeast were purchased from a local market in Makurdi. Orange fleshed sweet potatoes were purchased at Agbo market in Vandeikya Local Government of Benue state. Equipments such as blender, mixer, kneader, bowl, knife, digital weighing scale, measuring cylinder, boiler, baking pans, stirrer and oven were obtained in the food processing laboratory of University of Agriculture Makurdi. All other chemicals used were of analytical grade.

\subsection{Preparation of Raw Materials}

\subsubsection{Preparation of Orange Fleshed Sweet Potato Flour}

The sweet potato flour was produced using the method described by [6]. The orange fleshed sweet potato tubers were peeled and cut into thin pieces manually. The potato slices were then first immersed in $1 \% \mathrm{NaCl}$ solution and in a solution containing potassium metabisulphite (1\%) and citric acid $(0.5 \%)$ for $30 \mathrm{~min}$ to prevent browning reactions and enhance the colour of the flour. Drying of sweet potato slices was done on perforated trays in a tray dryer (M/s. Balaji Enterprises, Saharanpur, India) at $55^{\circ} \mathrm{C}$ till constant weight. The dried sweet potato chips were milled into flour using the laboratory grinder (M/s. Sujata, New Delhi, India) and passed through $250 \mu \mathrm{m}$ mesh sieve, packed in airtight containers and stored in the refrigerator till further use. The flow chart for the production of sweet potato flour is shown in Figure 1.

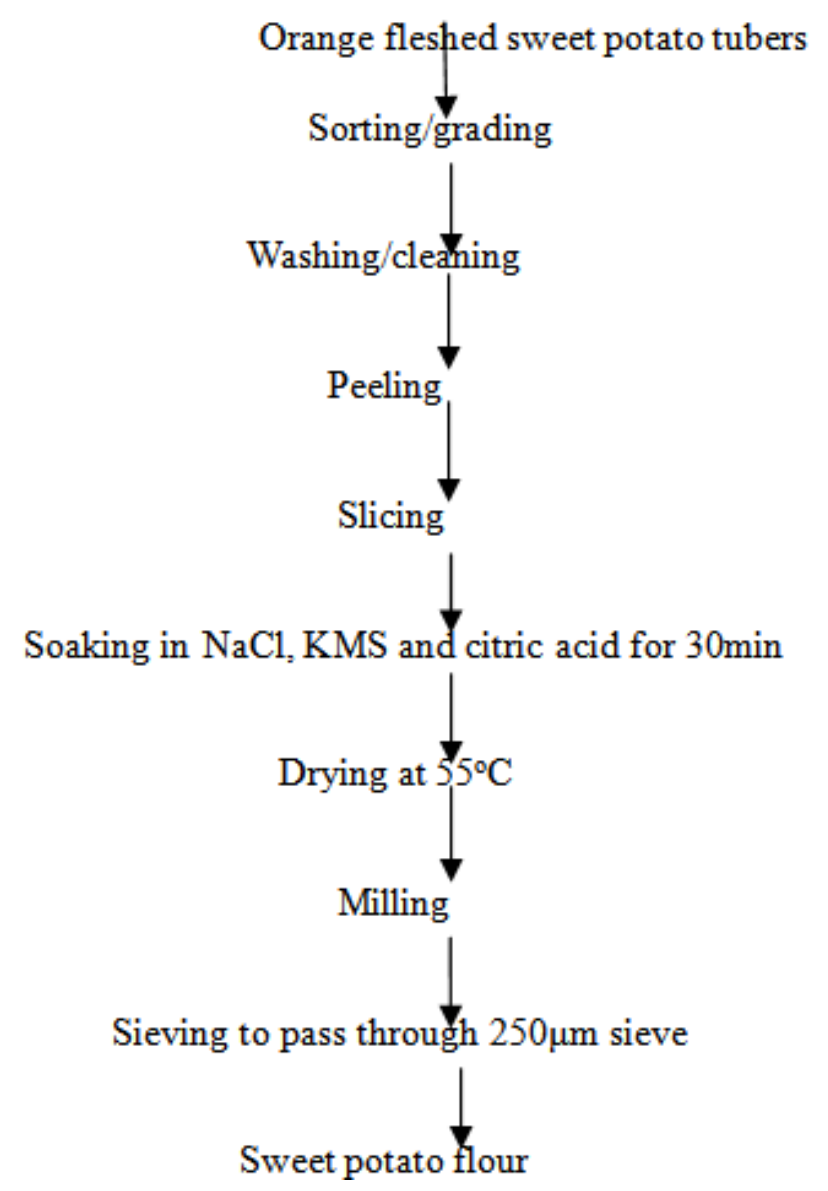

Figure 1. Flow chart for production of orange fleshed sweet potato flour. Source: Modified Singh et al., (2008)

\subsubsection{Preparation of Yellow Maize Flour}

The method of [21] was used to prepare the maize flour. Yellow maize kernels were sorted to remove stones, dirt and other foreign materials. Water was sprinkled on cleaned maize seeds so as to allow absorption of water by the grains, toughening the pericarp and germ so they do not splinter during milling. The grains were left for about $10 \mathrm{~min}$ before dehulling and milling. The flour was sieved using $250 \mu \mathrm{m}$ mesh size as shown in Figure 2.

\subsection{Formulation of Composite Flour and other Ingredients for Bread Production}

Five different samples of bread were produced and coded as A, B, C, D and E. Sample A served as the control 
and contained $100 \%$ wheat. Samples A, B, C and D consisted of wheat/maize/potato flours and the other ingredients for bread production are presented in Table 1.

Table 1. Recipe formulation for bread production. Source: Modified Islam et al., (2011)

\begin{tabular}{|c|c|c|c|c|c|}
\hline \multicolumn{7}{|c|}{ SAMPLES } \\
\hline INGREDIENTS & A & B & C & D & E \\
\hline Wheat flour (g) & 100 & 90 & 80 & 70 & 60 \\
\hline maize (g) & 0 & 5 & 10 & 15 & 20 \\
\hline Sweet potato (g) & 0 & 5 & 10 & 15 & 20 \\
\hline Salt (g) & 2.5 & 2.5 & 2.5 & 2.5 & 2.5 \\
\hline Yeast (g) & 2.5 & 2.5 & 2.5 & 2.5 & 2.5 \\
\hline Fats (g) & 2 & 2 & 2 & 2 & 2 \\
\hline Sugar (g) & 2 & 2 & 2 & 2 & 2 \\
\hline Water (ml) & 65 & 65 & 65 & 65 & 6 \\
\hline
\end{tabular}

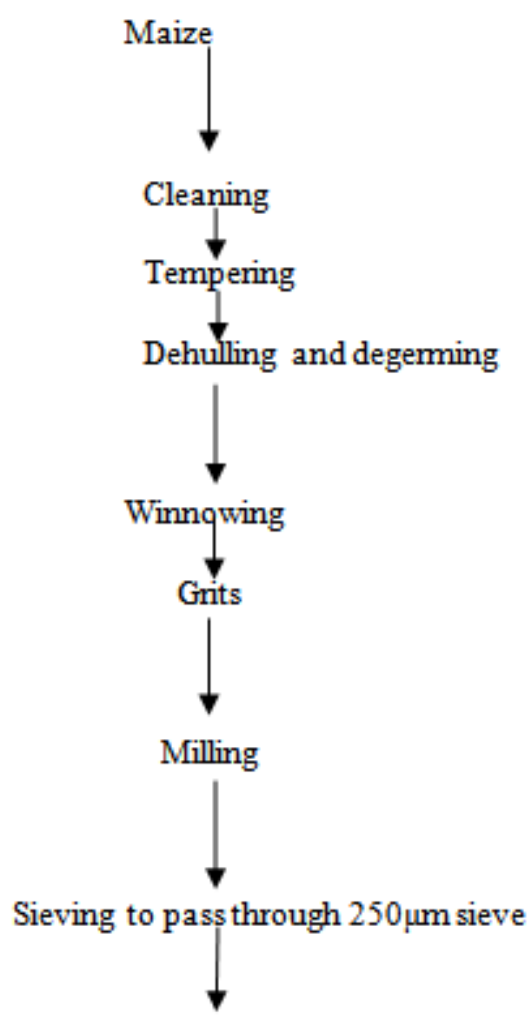

Maize flour

Figure 2. Production of Maize flour. Source: Houssou and Ayemor (2002)

\subsection{Bread Production by the Straight Dough Method}

The straight dough method was used to produce the bread. This method involves the addition of all the ingredients (flour, salt, water, sugar, yeast etc) at mixing stage and kneading same to obtain the dough [23]. The different dough samples were placed in baking pans smeared with vegetable oil and was covered for the dough to ferment resulting in gas production and gluten development for about 1 hour. The dough was then baked in the oven at $230^{\circ} \mathrm{C}$ for 30 minutes. The baked loaves were carefully removed from the pans and allowed to cool and packaged in polyethylene bags for analysis. The flow chart for bread production is shown in Figure 3.

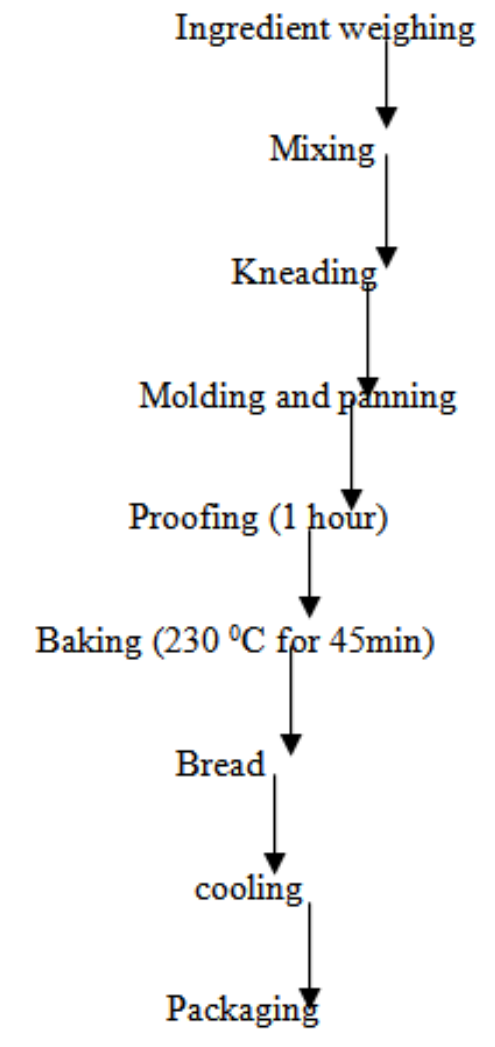

Figure 3. Flow chart for bread production

\subsection{Determination of Physical Properties of The Bread Loaves}

The Loaf volume was measured by seed displacement method of [25]. Loaf weight was determined by simple weighing using an electronic balance while Specific volume was obtained by dividing the loaf volume of bread by its corresponding loaf weight. Thus, Specific volume = $\mathrm{v} / \mathrm{wt}\left(\mathrm{cm}^{3} / \mathrm{g}\right)$.

\subsection{Determination of Proximate Composition of Bread Loaves.}

Proximate analysis was carried out on the bread loaves to determine the moisture, ash, crude fibre, fat, protein and carbohydrate content.

\subsubsection{Moisture Content}

The moisture content was determined by hot air oven method as described by [26]. An empty crucible was weighed and $2 \mathrm{~g}$ of the sample was transferred into the crucible. This was taken into the hot air oven and dried for 24 hours at $100^{\circ} \mathrm{C}$. The crucible and its contents were cooled in the desicator and their weights taken. The loss in weight was regarded as moisture content and expressed as;

$$
\% \text { moisture }=\frac{\text { weight loss }}{\text { weight of sample }} \times 100
$$

\subsubsection{Ash Content}

Ash content was determined using the method of [26]. About $5 \mathrm{~g}$ of each sample was weighed into crucibles in duplicate, and then the sample was incinerated in a muffle furnace at $550^{\circ} \mathrm{C}$ until a light grey ash was observed and a constant weight obtained. The sample was cooled in the 
desiccator to avoid absorption of moisture and weighed to obtain ash content.

$$
\operatorname{Ash}(\%)=\frac{\text { weight of ash }}{\text { weight of sample }} \times 100
$$

\subsubsection{Crude Fibre}

Crude fibre was determined using the method of [26] About $5 \mathrm{~g}$ of each sample was weighed into a $500 \mathrm{ml}$ Erlenmeyer flask and $100 \mathrm{ml}$ of TCA digestion reagent was added. It was then brought to boiling and refluxed for exactly 40 minutes counting from the start of boiling. The flask was removed from the heater, cooled a little then filtered through a $15.0 \mathrm{~cm}$ number 4 Whatman paper. The residue was washed with hot water stirred once with a spatula and transferred to a porcelain dish. The sample was dried overnight at $105^{\circ} \mathrm{C}$. After drying, it was transferred to a desiccator and weighed as $\mathrm{W}_{1}$. It was then burnt in a muffle furnace at $500^{\circ} \mathrm{C}$ for 6 hours, allowed to cool, and reweighed as $\mathrm{W}_{2}$.

$$
\begin{aligned}
& \% \text { crude fibre }=\frac{W_{1-W_{2}}}{W_{0}} \times 100 \\
& W_{1}=\text { weight of crucible+fiber+ash } \\
& W_{2}=\text { weight of crucible+ash } \\
& W_{0}=\text { Dry weight of food sample }
\end{aligned}
$$

\subsubsection{Fat Content}

The soxhlet extraction method described by [26] was used in determining fat content of the samples. About $2 \mathrm{~g}$ of the sample was weighed and the weight of the flat bottom flask taken with the extractor mounted on it. The thimble was held half way into the extractor and the weighed sample. Extraction was carried out using (boiling point $40-60^{\circ} \mathrm{C}$ ). The thimble was plugged with cotton wool. At completion of extraction which lasted for 8 hours, the solvent was removed by evaporation on a water bath and the remaining part in the flask was dried at $80^{\circ} \mathrm{C}$ for 30 minutes in the air oven to dry the fat and then cooled in a dessicator. The flask was reweighed and percentage fat calculated as

$$
\% \text { Fat }=\frac{\text { weight loss }}{\text { weight of sample }} \times 100
$$

\subsubsection{Protein Content}

The micro Kjedal method as described by [26] was used to determine crude protein. About $2 \mathrm{~g}$ of the sample was put into the digestion flask. Ten grams of copper sulphate and sodium sulphate (catalyst) in the ratio 5:1 respectively and $25 \mathrm{ml}$ concentrated sulphuric acid were also added to the digestion flask. The flask was placed into the digestion block in the fume cupboard and heated until frothing ceased giving clear and light blue green coloration. The mixture was then allowed to cool and diluted with distilled water until it reached $250 \mathrm{ml}$ of volumetric flask. Distillation apparatus was connected, and $10 \mathrm{ml}$ of the mixture was poured into the receiver of the distillation apparatus also $10 \mathrm{ml}$ of $40 \%$ sodium hydroxide was added. The released ammonia by boric acid was then treated with $0.02 \mathrm{~m}$ of hydrochloric acid until the green color change to purple. Percentage of nitrogen in the sample was calculated using the formula below:

$$
\begin{aligned}
& \text { Nitrogen }(\%)= \\
& \frac{(\text { Titre }- \text { Blank }) \times 14.008 \times \text { Normality }}{\text { weight of sample }} \times 100 \\
& \% \text { crude protein }=\% \text { Nitrogen X } 6.25
\end{aligned}
$$

\subsubsection{Determination of Carbohydrate Content}

The carbohydrate content was calculated by difference according to[27].

\subsection{Determination of Mineral Content}

The mineral content of the bread samples was determined by using the method described by [26]. The ash obtained from the ash analysis earlier was used in the determination of the minerals content. The ash was placed in porcelain crucibles, then few drops of distilled water were added, followed by $2 \mathrm{ml}$ of concentrated hydrochloric acid. $10 \mathrm{ml}$ of $20 \% \mathrm{HNO}_{3}$ were added, evaporated on the hot plate. The samples were filtered through Whiteman filter paper into $100 \mathrm{ml}$ volumetric flask. The mineral elements; iron, magnesium and calcium were determined by atomic absorbance spectrophotometer. (AA800 perkinElmer, Germany). The phosphorus in the sample filtrate was determined using Vanadomolybdate reagent at 400 nm using colorimetric method (Colorimeter SP20, Bausch and Lamb).

\subsection{Determination of B-Carotene Content}

$\beta$-carotene was determined using the method of [28]. Five grams of bread crumbs was weighed into a separating funnel $(250 \mathrm{ml}), 2 \mathrm{ml}$ of $\mathrm{NaCl}$ solution was introduced into it and shaken vigorously, followed by $10 \mathrm{ml}$ of ethanol, then $20 \mathrm{ml}$ of methane. The mixture was shaken vigorously for 5 minutes and allowed to stand for 30 minutes after which the lower layer was ran off. The absorbance of the top layer was determined at a wavelength of $460 \mathrm{~nm}$ using a Hachdrel/5 model spectrophotometer (England).

$$
\begin{aligned}
& \text { Total carotenoid }\left(\frac{m g}{100}\right)= \\
& \frac{\text { Absorbance }}{\text { Specific extinction coefficient } \times \text { path length of cell }} \\
& \text { Where, molar extinction coefficient }\left(\sum\right)=15 \times 10^{-4} \\
& \text { Specific extinction efficient }=\sum \times \text { molar mass of beta- } \\
& \text { carotene } \\
& \text { Molar mass of bête-carotene }=536.88 \mathrm{~g} / \mathrm{mol} \text {. } \\
& \text { Path length of cell }=1 \mathrm{~cm}
\end{aligned}
$$

\subsection{Sensory Evaluation}

The five samples of bread were coded and presented to fifteen member panel of judges who are familiar with the product for sensory evaluation. The panelists scored the colour, flavor, taste, texture and overall acceptability of the bread using a nine point hedonic scale, where 9 indicates extremely like and 1 extremely dislike [27].

\subsection{Statistical Analysis}

All analytical determinations were conducted in duplicates. Means and standard deviations were calculated. 
Data obtained was subjected to analysis of variance (ANOVA) [29] where significant differences existed, Tukey's test was used in separating the means described by [27].

\section{Results and Discussion}

\subsection{Physical Properties of Bread Loaves}

The physical characteristics of the bread from wheat/maize/sweet potato flour blends are presented in Table 2. The loaf volume and specific volume of the bread decreased significantly $(\mathrm{P}<0.05)$ with increased substitution with yellow maize and OFSW flours. Sample A with $100 \%$ wheat flour recorded the highest values of $340 \mathrm{~cm}^{3}$ and $1.35 \mathrm{~cm}^{3} / \mathrm{g}$ for loaf volume and specific volume while sample $\mathrm{E}$ had the lowest values of $182 \mathrm{~cm}^{3}$ and $0.99 \mathrm{~cm}^{3} / \mathrm{g}$, for loaf volume and specific volume respectively. This could be attributed to the decrease in structure forming proteins in wheat which lowered the ability of the dough to rise during proofing leading to reduction in the bread volume. The loaf weight of maize/sweet potato composite bread increased significantly $(\mathrm{p}<0.05)$ with increasing levels of yellow maize and orange fleshed potato flours. The weights of all the maize and orange fleshed potato based bread were significantly higher than $100 \%$ wheat bread. The same trend was observed by $[4,19,30]$ in bread production from different composite flours.

Table 2. physical characteristics of wheat/ maize/ sweet potato bread samples

\begin{tabular}{|c|c|c|c|c|c|c|}
\hline \multicolumn{7}{|c|}{ Samples } \\
\hline $\begin{array}{c}\text { Param } \\
\text { eters }\end{array}$ & A & B & C & D & E & $\begin{array}{c}\text { LS } \\
\text { D }\end{array}$ \\
\hline $\begin{array}{c}\text { loaf } \\
\text { volum } \\
\text { e }\left(\mathrm{cm}^{3}\right)\end{array}$ & $\begin{array}{c}340 \pm 1.0 \\
0^{\mathrm{a}}\end{array}$ & $\begin{array}{c}256 \pm 1 . \\
00^{\mathrm{b}}\end{array}$ & $\begin{array}{c}220 \pm 0.0 \\
6^{\mathrm{c}}\end{array}$ & $\begin{array}{c}200 \pm 1.0 \\
0^{\mathrm{d}}\end{array}$ & $\begin{array}{c}182 \pm 0.0 \\
5^{\mathrm{e}}\end{array}$ & $\begin{array}{c}2.8 \\
5\end{array}$ \\
\hline $\begin{array}{c}\text { loaf } \\
\text { weight } \\
(\mathrm{g})\end{array}$ & $\begin{array}{c}183.84 \pm \\
0.05^{\mathrm{e}}\end{array}$ & $\begin{array}{c}200 \pm 1 . \\
00^{\mathrm{d}}\end{array}$ & $\begin{array}{c}217.82 \pm \\
0.06^{\mathrm{c}}\end{array}$ & $\begin{array}{c}240.98 \pm \\
1.00^{\mathrm{b}}\end{array}$ & $\begin{array}{c}251.85 \pm \\
1.00^{\mathrm{a}}\end{array}$ & $\begin{array}{c}2.6 \\
7\end{array}$ \\
\hline $\begin{array}{c}\text { LSV } \\
\left(\mathrm{cm}^{3} / \mathrm{g}\right.\end{array}$ & $\begin{array}{c}1.85 \pm 0.0 \\
1^{\mathrm{a}}\end{array}$ & $\begin{array}{c}1.28 \pm 0 \\
.02^{\mathrm{b}}\end{array}$ & $\begin{array}{c}1.01 \pm 0.0 \\
5^{\mathrm{b}}\end{array}$ & $0.83 \pm$ & $\begin{array}{c}0.72 \pm 0.0 \\
6^{\mathrm{c}}\end{array}$ & $\begin{array}{c}0.0 \\
1\end{array}$ \\
\hline
\end{tabular}

Values are means \pm SD duplicate determinations

Values with different superscript within the same row are significantly different $(\mathrm{p}<0.05)$

$\mathrm{LSD}=$ Least significant difference.

LSV $=$ Loaf specific volume

$A=100 \%$ wheat flour (control); $B=90 \%$ wheat, $5 \%$ maize, $5 \%$ sweet potato; $\mathrm{C}=80 \%$ wheat flour, $10 \%$ maize, $10 \%$ sweet potato; $\mathrm{D}=70 \%$ wheat, $15 \%$ maize, $15 \%$ sweet potato; $\mathrm{E}=60 \%$ wheat, $20 \%$ maize, $20 \%$ sweet potato.

\subsection{Proximate Composition of Bread Loaves}

The result of the proximate composition of bread from wheat/maize/sweet potato flour blends is shown in Table 3 . The moisture and protein contents of the bread loaves decreased significantly $(\mathrm{p}<0.05)$ with increasing levels of maize and sweet potato flours. The $100 \%$ wheat bread recorded $34.97 \%$ moisture and $13.12 \%$ protein while composite bread consisting of $60 \%$ wheat, $20 \%$ maize and $20 \%$ sweet potato recorded $29.97 \%$ moisture and $7.65 \%$ protein. The decrease in moisture content of the bread samples with increasing levels of composite flour may increase the shelf life of the bread while the decrease in protein content could be attributed to the low protein content of maize and sweet potato flours. This implies that bread with the low protein content should be consumed with other protein rich diet to make up for the low protein. The fat, ash, fibre and carbohydrate contents of the bread increased with increasing levels of maize/sweet potato flours. The increased fat content could be attributed to the high fat content in maize and the increased ash content could come from both maize and sweet potato which are reported to contain high minerals. Similar result was reported by [31]. The increase in fibre and carbohydrate could also be attributed to the maize and sweet potato flours which are reported to be high in both nutrients $[31,32,33]$. This implies that the bread would be a source of high energy and nutrients dense food for consumers. According to [34] crude fibre contributes to the health of the gastrointestinal system and metabolic system in man.

Table 3. proximate composition of wheat/ maize/ sweet potato bread samples

\begin{tabular}{|c|c|c|c|c|c|c|}
\hline \multicolumn{7}{|c|}{ Samples } \\
\hline $\begin{array}{c}\text { Paramet } \\
\text { ers (\%) }\end{array}$ & $\mathrm{A}$ & $\mathrm{B}$ & $\mathrm{C}$ & $\mathrm{D}$ & $\mathrm{E}$ & $\begin{array}{c}\text { LS } \\
\mathrm{D}\end{array}$ \\
\hline Moisture & $\begin{array}{c}34.97 \pm \\
0.05^{\mathrm{a}}\end{array}$ & $\begin{array}{c}29.93 \pm \\
1.06^{\mathrm{c}}\end{array}$ & $\begin{array}{c}29.70 \pm \\
0.02^{\mathrm{d}}\end{array}$ & $\begin{array}{c}30.33 \pm \\
1.57^{\mathrm{b}}\end{array}$ & $\begin{array}{c}29.97 \pm \\
0.05^{\mathrm{c}}\end{array}$ & $\begin{array}{c}0.0 \\
47\end{array}$ \\
\hline \multirow{2}{*}{ Protein } & $13.12 \pm$ & $12.02 \pm$ & $10.96 \pm$ & $8.76 \pm 0$. & $7.65 \pm 0$. & 0.0 \\
& $0.02^{\mathrm{a}}$ & $0.01^{\mathrm{b}}$ & $0.03^{\mathrm{c}}$ & $01^{\mathrm{d}}$ & $01^{\mathrm{e}}$ & 31 \\
\hline \multirow{2}{*}{ Fat } & $2.96 \pm 0$. & $3.52 \pm 0$. & $3.78 \pm 0$. & $4.53 \pm 0$. & $5.50 \pm 0$. & 0.0 \\
& $06^{\mathrm{e}}$ & $08^{\mathrm{d}}$ & $02^{\mathrm{c}}$ & $06^{\mathrm{b}}$ & $02^{\mathrm{a}}$ & 92 \\
\hline Crude & $0.77 \pm 0$. & $0.79 \pm 0$. & $0.84 \pm 0$. & $0.89 \pm 0$. & $0.95 \pm 0$. & 0.0 \\
fibre & $03^{\mathrm{e}}$ & $01^{\mathrm{d}}$ & $01^{\mathrm{c}}$ & $06^{\mathrm{b}}$ & $01^{\mathrm{a}}$ & 22 \\
\hline \multirow{2}{*}{ Ash } & $1.39 \pm 0$. & $1.48 \pm 0$. & $2.03 \pm 0$. & $2.49 \pm 0$. & $2.97 \pm 0$. & 0.0 \\
& $01^{\mathrm{e}}$ & $03^{\mathrm{d}}$ & $05^{\mathrm{c}}$ & $02^{\mathrm{b}}$ & $05^{\mathrm{a}}$ & 71 \\
\hline Carbohy & $46.71 \pm$ & $52.18 \pm$ & $52.42 \pm$ & $52.85 \pm$ & $53.35 \pm$ & 0.0 \\
drate & $0.01^{\mathrm{e}}$ & $0.02^{\mathrm{d}}$ & $0.01^{\mathrm{c}}$ & $0.05^{\mathrm{b}}$ & $0.01^{\mathrm{a}}$ & 49 \\
\hline
\end{tabular}

Values are means \pm SD duplicate determinations

Values with different superscript within the same row are significantly different $(\mathrm{p}<0.05)$

$\mathrm{LSD}=$ Least significant difference.

$\mathrm{A}=100 \%$ wheat flour (control); $\mathrm{B}=90 \%$ wheat, $5 \%$ maize, $5 \%$ sweet potato; $\mathrm{C}=80 \%$ wheat flour, $10 \%$ maize, $10 \%$ sweet potato; $\mathrm{D}=70 \%$ wheat, $15 \%$ maize, $15 \%$ sweet potato; $E=60 \%$ wheat, $20 \%$ maize, $20 \%$ sweet potato.

\subsection{Mineral/ Vitamin Composition of the Bread Samples}

The mineral/ vitamin composition of the composite bread is presented in Table 4 . The calcium and $\beta$-carotene contents of the bread increased significantly with increase in maize and sweet potato flours from $0.73-1.11 \mathrm{mg} / 100 \mathrm{~g}$ and 0.58-4.56 mg/100 g respectively. The work reported on maize and sweet potato showed that these crops are rich in nutrients. [35,36]. Calcium is necessary for supporting bone formation and growth. The increased $\beta$ carotene content could be from both the yellow specie of maize and orange fleshed potato flours. These crops are reported to be high in $\beta$-carotene, [5]. The $\beta$-carotene which is pro vitamin $A$ is an essential nutrient required for maintaining immune function [37]. It also helps in the maintenance of healthy teeth, skeletal and soft tissue, mucous membranes and skin. It is often known as retinol because it produces the pigment in the retina of the eye. The values for magnesium, phosphorus and iron showed no definite trend but varied significantly $(\mathrm{P}<0.05)$ from one another. Magnesium is essential to good health because it helps to maintain normal muscle and nerve function, keeps heart rhythm steady, supports a healthy immune system and keeps bones strong. Phosphorus works closely with calcium to build strong bones and teeth. 
It is stored in the bone as calcium phosphate. Bread rich in these nutrients would enhance the health of both children and adults.

Table 4. Minerals / Vitamin content of wheat/ maize/ sweet potato bread samples

\begin{tabular}{|c|c|c|c|c|c|c|}
\hline \multicolumn{7}{|c|}{ Samples } \\
\hline $\begin{array}{c}\text { Parameters(m } \\
\text { g/100g) }\end{array}$ & $\mathrm{A}$ & $\mathrm{B}$ & $\mathrm{C}$ & $\mathrm{D}$ & $\mathrm{E}$ & $\begin{array}{c}\text { LS } \\
\mathrm{D}\end{array}$ \\
\hline \multirow{2}{*}{ Calcium } & $0.73 \pm 0$ & $0.76 \pm 0$. & $0.84 \pm$ & $0.96 \pm 0$ & $1.11 \pm 0$ & 0.0 \\
& $.01^{\mathrm{e}}$ & $01^{\mathrm{d}}$ & $0.01^{\mathrm{c}}$ & $.01^{\mathrm{b}}$ & $.01^{\mathrm{a}}$ & 36 \\
\hline \multirow{2}{*}{ Magnesium } & $0.55 \pm 0$ & $0.37 \pm 0$. & $0.67 \pm$ & $0.45 \pm 0$ & $0.58 \pm 0$ & 0.0 \\
& $.01^{\mathrm{c}}$ & $01^{\mathrm{e}}$ & $0.02^{\mathrm{a}}$ & $.01^{\mathrm{d}}$ & $.01^{\mathrm{b}}$ & 33 \\
\hline \multirow{2}{*}{ Phosphorous } & $0.06 \pm 0$ & $0.07 \pm 0$. & $0.05 \pm$ & $0.07 \pm 0$ & $0.05 \pm 0$ & 0.0 \\
& $.01^{\mathrm{c}}$ & $01^{\mathrm{a}}$ & $0.01^{\mathrm{e}}$ & $.01^{\mathrm{b}}$ & $.01^{\mathrm{d}}$ & 01 \\
\hline \multirow{2}{*}{ Iron } & $3.31 \pm 0$ & $03.16 \pm$ & $1.99 \pm$ & $2.67 \pm 0$ & $3.38 \pm 0$ & 0.0 \\
& $.01^{\mathrm{b}}$ & $0.01^{\mathrm{c}}$ & 0.01 & $.01^{\mathrm{d}}$ & $.01^{\mathrm{a}}$ & 37 \\
\hline \multirow{2}{*}{ 3-carotene } & $0.58 \pm 0$ & $0.59 \pm 0$. & $2.26 \pm$ & $3.55 \pm 0$ & $4.56 \pm 0$ & 0.0 \\
& $.01^{\mathrm{e}}$ & $01^{\mathrm{d}}$ & $0.10^{\mathrm{c}}$ & $.01^{\mathrm{b}}$ & $.02^{\mathrm{a}}$ & 41 \\
\hline
\end{tabular}

Values are means \pm SD duplicate determinations

Values with different superscript within the same row are significantly different $(\mathrm{p}<0.05)$

$\mathrm{LSD}=$ Least significant difference.

$\mathrm{A}=100 \%$ wheat flour (control); $\mathrm{B}=90 \%$ wheat, $5 \%$ maize, $5 \%$ sweet potato; $C=80 \%$ wheat flour, $10 \%$ maize, $10 \%$ sweet potato; $D=70 \%$ wheat, $15 \%$ maize, $15 \%$ sweet potato; $E=60 \%$ wheat, $20 \%$ maize, $20 \%$ sweet potato.

\subsection{Sensory Evaluation of the Bread Loaves}

The result of the mean sensory scores is presented in Table 5. The scores for overall acceptability and appearance varied from 7.27-6.6 and 7.47-6.93 respectively. There was decrease in the scores as maize and sweet potato flours were added however the decrease was not significant $(\mathrm{P}>0.05)$. The result revealed that the texture and taste of the bread varied significantly $(\mathrm{P}<0.05)$ between the (control) sample A with $100 \%$ wheat and the other samples B to E incorporated with maize and sweet potato flours. In general all the bread samples compared well with the control sample, and were well accepted. The study has shown that maize/sweet potato flour could be used with wheat as composite flours to produce acceptable bread.

Table 5. Mean Sensory Scores of Bread produced from wheat/ maize/ sweet potato flour blends

\begin{tabular}{ccccccc}
\hline $\begin{array}{c}\text { Samples } \\
\text { Attributes }\end{array}$ & A & B & C & D & E & LSD \\
\hline Taste & $7.20^{\mathrm{a}}$ & $6.87^{\mathrm{b}}$ & $6.47^{\mathrm{b}}$ & $6.67^{\mathrm{b}}$ & $6.80^{\mathrm{b}}$ & 1.28 \\
Flavour & $7.01^{\mathrm{a}}$ & $6.80^{\mathrm{b}}$ & $6.07^{\mathrm{b}}$ & $5.80^{\mathrm{b}}$ & $6.47^{\mathrm{b}}$ & 1.23 \\
Texture & $7.20^{\mathrm{a}}$ & $6.67^{\mathrm{b}}$ & $6.60^{\mathrm{b}}$ & $6.27^{\mathrm{b}}$ & $7.13^{\mathrm{b}}$ & 1.12 \\
Appearance & $7.47^{\mathrm{a}}$ & $6.93^{\mathrm{a}}$ & $7.20^{\mathrm{a}}$ & $6.93^{\mathrm{a}}$ & $7.33^{\mathrm{a}}$ & 1.01 \\
Overall acceptability & $7.27^{\mathrm{a}}$ & $6.73^{\mathrm{a}}$ & $6.87^{\mathrm{a}}$ & $6.60^{\mathrm{a}}$ & $7.27^{\mathrm{a}}$ & 1.05 \\
\hline
\end{tabular}

Values are means \pm SD duplicate determinations

Values with different superscript within the same row are significantly different $(\mathrm{p}<0.05)$

LSD $=$ Least significant difference.

$\mathrm{A}=100 \%$ wheat flour (control); $\mathrm{B}=90 \%$ wheat, $5 \%$ maize, $5 \%$ sweet potato; $\mathrm{C}=80 \%$ wheat flour, $10 \%$ maize, $10 \%$ sweet potato; $\mathrm{D}=70 \%$ wheat, $15 \%$ maize, $15 \%$ sweet potato; $\mathrm{E}=60 \%$ wheat, $20 \%$ maize, $20 \%$ sweet potato.

\section{Conclusion}

The study has shown that 20\% yellow maize and $20 \%$ orange fleshed sweet potato could be used as wheat substitute to produce bread that would be well accepted by the consumers. The bread produced from wheat, yellow maize and orange fleshed potato had increased nutrients of carbohydrate, fibre, fat, ash, calcium and $\beta$-carotene-the precursor of vitamin A. Thus, the bread would enhance the health, growth and well being of the consumers. The use of maize and sweet potato in bread production would promote production, value addition and diversification of utilization of the crops in Nigeria and environs. This would create wealth and enhance food security.

\section{Statement of Competing Interests}

The authors have no competing interest.

\section{References}

[1] Dewettinck, K., Bockstaele, V., Kuhne, F., Van de Walle, B. Courtens, T. and Gellynck, X (2008). Nutritional value of bread: Influence of processing, food interaction and consumer perception Rev. J. Cereal sci., 48: 243-257.

[2] Aider, M. Sirois-Gosselin, M. \& Boye, J.I. (2012) Pea, Lentil and Chickpea Protein Application in Bread making Journal of Food Research; Vol. 1, No. 4.

[3] David MO (2006). Nigeria No. 1 Market for U.S. wheat: Potential for other grains and seeds. Foreign Agric. Serv. Bull. pp. 1-2.

[4] Olaoye, O.A., A.A. Onilude and O.A. Idowu, 2006. Quality characteristics of bread produced from composite flours of wheat, plantain and soybeans. Afri. J. Biotechnol., 11: 1102-1106.

[5] Woolfe, J.A., (1992). Sweet potato; an untapped food resource. Cambridge University Press, New York UK., pp 1-39.

[6] Singh, S., C.S Ria and D.C. Saxena, (2008). Effect of incorporating sweet potato flour to wheat flour on the quality characteristics of cookies. Afr. J. Food sci., 2: 65-7.

[7] WHO (World Health Organization). 1995. Global prevalence of vitamin A deficiency. Micronutrient Deficiency Information System, Working Paper \#2 (Catalog \# WHO/NUT/95.3). WHO, Geneva, Switzerland.

[8] Odebode, S.O., N. Egeonu and M.O. Akoroda, 2008. Promotion of sweet potato for the food industry in Nigeria. Bulgarian J. Agric. Sci., 14: 300-308.

[9] Samapundo S., B. De Meulenaer, D. Osei-Nimoh, Y.B. Lamboni, J.M. Debevere and F. Devlieghere, 2007. Can phenolic compounds be used for the protection of corn from fungal invasion and mycotoxin contamination during storage Food Microbiology 24, 465-473.

[10] WHO (World Health Organization). 1995. Global prevalence of vitamin A deficiency. Micronutrient Deficiency Information System, Working Paper \#2 (Catalog \# WHO/NUT/95.3). WHO, Geneva, Switzerland.

[11] Odebode, S.O., 2004. Promotion of high quality sweet potato flour in the food industry; evidence from rural women. University of Ibadan press, Ibadan Nigeria, pp 2.

[12] Ulm SG (1988). The Effect of Storage Conditions on Selected Quality Attributes of Sweet potato Flour, Thesis of the University Tennessee, Knoxville. p. 7-26.

[13] Agbor-Egbe, T. and Richard, J. E. 1990. Evaluation of the chemical composition of fresh and stored edible aroids. J. Sci. Food Agric., 53: 487-495.

[14] Purseglove, J. W. (1991). Tropical crops. Dicotyledons. New York: Longman Scientific and Technical.. John Wiley and Sons Inc., pp. 58-65.

[15] Ofori, G., I. W.O. Ellis and K.H. Dapaah, 2009. assesssment of vitamin A content and sensory attributes of new sweet potato (Ipomeoa batatas) genotypes in Ghana. Afr. J. Food sc., 3: 184192.

[16] Shittu, S. T., Oyeyemi, W. A., Okewumi, T. A. and Salman, T. M. Role of oxidative stress in therapeutic administration of artesunate on sperm quality and testosterone level in male albino rats African Journal of Biotechnology Vol. 12 (1), pp. 70-73, 2 January, 2013.

[17] Ammar, M.S., A.E. Hegazy and S.H. Bedei, 2009. Using of Taro flour as partial substitute of wheat flour in Bread making. World J. Dairy Food Sci., 4: 94-99.

[18] Shittu TA, Dixon A, Awonorin SO, Sanni LO, Maziyadixon B (2008). Bread from composite cassava genotype and nitrogen fertilizer on bread quality. Food Res. Int., 41: 568-578. 
[19] Ade-Omowaye, B.I.O., B.A. Akinwande, I.F. Bolarinwa and A.O. Adebiyi, 2008. Evaluation of tigernut (Cyperus esculentus) wheat composite flour and bread. Afr. J. Food Sci., 2: 87-91.

[20] Khan (2005). Effect of soy-flour supplementation on mineral and phytate contents of unleavened flat bread (chapattis.) J.of Nutrition Bulletin 3: 322-168.

[21] Houssou P, Ayemor GS (2002). Appropriate processing and food functional property of maize flour. African Journal of Science and Technology 3: 126-131.

[22] Islam M.Z, Shams-Ud-Din and Haque M.A. (2011). Studies on the effect of brown rice and maize flour on the quality of bread. J. Bangladesh Agril. Univ. 9 (2): 297-304.

[23] Chauhan GS, Zillman RR and NAM Eskin Dough mixing and bread making properties of quinoa-wheat flour blends. International Journal of Food Science and Technology. 1992; 27: 701-705.

[24] Walter, W.M., V.D. Truong and K.E. Sylvia, 2001. Methods In: Roots, Tubers, Plantains and Bananas inHuman Nutrition. FAO Food and Nutrition Series, No. 24, pp: 121-139.

[25] Giami, S.Y, Adindu, M.N., Akusu, M.O. and Emenike J.N.T. (2004). Compositional, functional and storage properties of flours from raw and heat processed African bread fruit (Treculia Africana Deene) seeds. Plant foods Human Nutrition. 55: 357-368.

[26] AOAC (2005). Official methods of analysis $18^{\text {th }}$ ed. Arlington, V.A Association of Official Analytical Chemist PP. 806-842.

[27] Ihekoronye, A.I. and Ngoddy, P.O. (1985). Integrated Food Science and Technology. Macmilian Publishers, New York. Pg 296-301.
[28] Chaturvedi, Y. and Nagar, R. (2001) Levels of $\beta$-carotene and effects of processing on selected fruits and vegetables of the zone of India. Plant foods for Human Nutrition 56: 127-132.

[29] Steele RGD and JH Torrie Principles and Procedures of Statistics. McGraw-Hill Book Company Inc. New York, USA. 1980.

[30] Onuegbu N. C., Ihediohanma N.C., Odunze O. F and Ojukwu M (2013) Efficiency of wheat: maize composite flour as affected by baking method in bread and cake production Sky Journal of Food Science Vol. 2 (8), pp. 005-013, December.

[31] Begum R, M. J. Uddin, M. A. Rahman and M. S. Islam (2013) Comparative study on the development of maize flour based composite bread J. Bangladesh Agril. Univ. 11 (1): 133-139.

[32] Van Hal M (2000). Quality of sweetpotato flour during processing and storage. Food Rev. Inter. 16: 1-37.

[33] Mis, A. 2000. Some methodological aspects of determining wet gluten quality by the Glutomatic Method (a laboratory note), International Agrophysics, 14, 263-267.

[34] Schneeman BO (2002) Gastrointestinal physiology and functions. British Journal of Nutrition.; 88 (2): 159-163

[35] Simonne, A.H., Kays, S.J., Koehler, P.I., and Eitenmiller, R.R. 1993. Assessment of ß-carotene content in sweetpotato breeding lines in relation to dietary requirements. Journal of Food Composition and Analysis 6: 336-345.

[36] Takahata, Y., Noda, T. and Nagata, T. 1993. HPLC determination of ß-carotene content of sweet potato cultivars and its relationship to color values. Japanese Journal of Breeding 43: 421-427.

[37] Stephensen, C.B., 2001. Vitamin A, infection and immune function. Ann. Rev. Nutr., 21: 167-192. 